ARTICLE

https://doi.org/10.1038/s41467-019-12090-z

\title{
Palladium-catalyzed $\alpha$-arylation for the addition of small rings to aromatic compounds
}

\author{
Zhi-Tao $\mathrm{He}^{1} \&$ John F. Hartwig (1) ${ }^{1}$
}

Small, strained rings have rigid, defined conformations and unique electronic properties. For these reasons, many groups seek to use these subunits to form biologically active molecules. We report a generally applicable approach to attach small rings to a wide range of aromatic compounds by palladium-catalyzed $\alpha$-arylation of cyclopropyl, cyclobutyl and azetidinyl esters. The direct $\alpha$-arylation of cyclopropyl esters and cyclobutyl esters is achieved in high yield by ensuring that the rate of coupling exceeds the rate of Claisen condensation. The $\alpha$ arylation of azetidines is achieved without ring opening of the strained saturated heterocycle by conducting the reactions with an azetidine derivative bearing a benzyl protecting group on nitrogen. Mechanistic studies show that the $\alpha$-arylation of small rings is challenging because of the weak acidity of $\alpha \mathrm{C}-\mathrm{H}$ bond (cyclopropanes), strong sensitivity of the strained esters to Claisen condensation (cyclobutatanes), or facile decomposition of the enolates (azetidinyl esters).

\footnotetext{
${ }^{1}$ Department of Chemistry, University of California, Berkeley, CA 94720, United States. Correspondence and requests for materials should be addressed to J.F.H. (email: jhartwig@berkeley.edu)
} 
T he unique electronic, steric, and conformational properties of small rings have led to an increased interest in methods to incorporate such structures into pharmaceutical and agrochemical candidates $^{1-5}$. For example, the rigid conformation and strong $\mathrm{C}-\mathrm{H}$ bonds of cyclopropanes have been stated to help achieve a range of properties, including enhanced binding and potency, increased metabolic stability, increased brain permeability, decreased plasma clearance, and reduced off-target effects $^{2}$. The combination of small rings and aromatic fragments is particularly attractive because aryl and heteroaryl units are prevalent in compounds valuable for medicinal chemistry and agrochemistry (Fig. 1a) ${ }^{6-15}$.

Palladium-catalyzed $\alpha$-arylation reactions have been studied extensively, since the initial work published by Buchwald, Miura, and our group ${ }^{16-23}$. However, documented efforts to develop direct methods to couple aryl halides with the esters of small rings (Fig. 1b), whether small carbocyclic or heterocyclic esters, have given no product or have been reported in two examples in patents to give few turnovers and modest yields that we have not been able to reproduce (vide infra) ${ }^{24-27}$. Reactions of Reformatsky reagents generated from alpha-bromo esters requiring multiple steps for preparation have been published ${ }^{28-30}$, and the reactions of small-ring nitriles as surrogates of the esters have been reported ${ }^{24,25,31}$, but the direct reactions of three-membered or four-membered ring carbocyclic or heterocyclic esters with aryl halides in the presence of base and a catalyst have not been published ${ }^{26,27}$. Because esters can be converted easily into a variety of functional groups, the coupling of esters with aryl halides would be the most valuable version of the coupling of a small-ring enolate.

The same properties of small rings that make them valuable substructures in biologically active molecules make the reactions of such structures difficult to develop. The acidities of $\mathrm{C}-\mathrm{H}$ bonds and electrophilicities of attached carbonyl groups are distinct from those of unstrained analogs, and the propensity to undergo ring opening under conditions of synthetic chemistry is well known. In particular, the lower acidity of cyclopropyl esters and the greater electrophilicity of cyclopropyl and cyclobutyl ester carbonyl groups, relative to those of unstrained esters, cause Claisen condensation to compete with coupling. The propensity of azetidines protected with typical carbamate substituents makes the enolates of such azetidines unstable. To overcome these challenges, ester derivatives that form the enolates in high yield, conditions to generate the enolates without condensation, catalysts with high activity to outcompete competing processes, and azetidine derivatives that resist ring opening are needed. Further, an assessment of the rates of deprotonation and rates of side reactions are needed to determine the properties of these ring systems that limit catalytic couplings.

Here, we report a widely applicable, one-step approach with readily accessible reagents for the attachment of small rings to aromatic compounds by palladium-catalyzed $\alpha$-arylation. The reactions of cyclopropyl esters occur in high yield with a catalyst precursor not used previously for the a-arylation of esters. Broadly applicable reactions of cyclobutyl and azetidinyl esters occur after identification of the origins of the low yields of the one prior example of each reaction and redesign of the reagents and conditions. The arylations of all three types of small rings now occur with broad scope in yields up to $99 \%$. Finally, an unusual combination of debenzylation and alkylation of the azetidine nitrogen occurs, and broadly applicable derivatizations of the nitrogen in the product from coupling of azetidines can be conducted. The synthesis of three biologically relevant molecules containing small rings demonstrates the value of these valuable $\alpha$ arylations.

\section{Results}

Development of the a-arylation of cyclopropyl esters. The coupling of cyclopropyl esters has not been reported previously, and recent literature documented the inability to identify conditions for this process, even by modern high-throughput methods ${ }^{24,25}$. Thus, less efficient, alternative routes have been

a Representative biologically active molecules
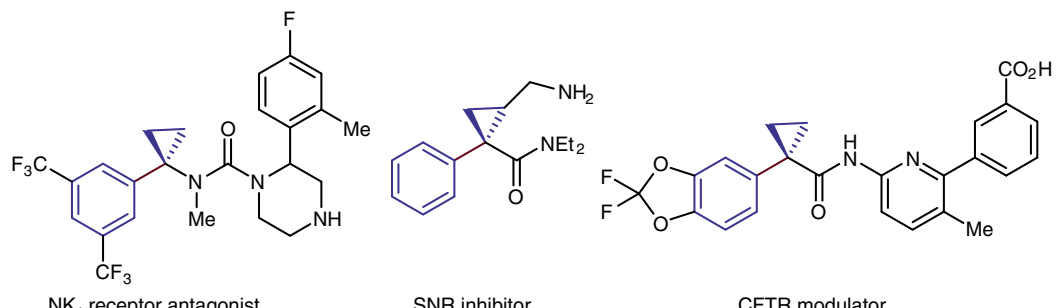<smiles>CC1(O)C[C@@H](O)[C@@](CC(C)(O)c2ccccn2)(c2cc(C(F)(F)F)ccn2)C1</smiles><smiles>[CH]C(C)CC(NC)C1(c2ccc(Cl)cc2)CCC1</smiles>

$\mathrm{NK}_{1}$ receptor antagonist

SNR inhibitor

CFTR modulator

TRPV3 antagonist

Monoamine reuptake inhibitor
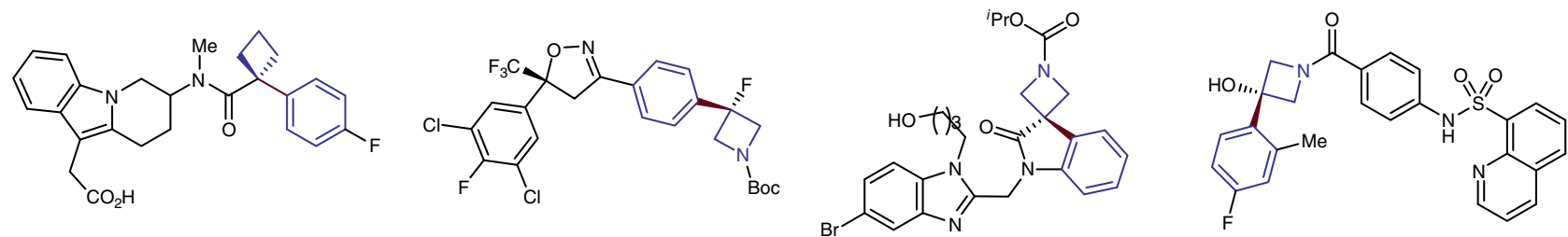

hCRTH2 antagonist

Antiparasitic activity

RSV inhibitor

PKM2 modulator

b Our strategy
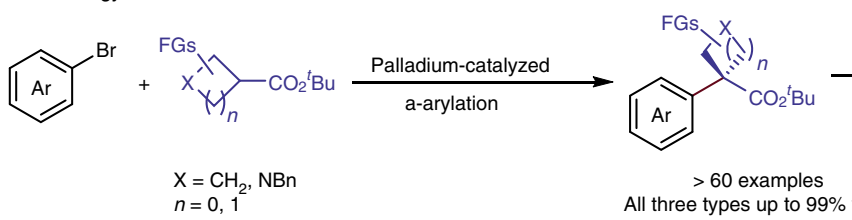

Many reliable

All three types up to $99 \%$ yield

Fig. 1 Representative biologically active molecules containing small rings and our strategy for their synthesis. a Selected biologically active molecules containing aryl-substituted small rings. b Our strategy for the introduction of small rings to aromatic compounds. FG: functional group 
used to produce $\alpha$-aryl cyclopropyl esters, such as reactions of unstable Reformatsky reagents requiring three steps for preparation of even the simplest zinc enolates ${ }^{28-30}$, or reactions of cyclopropyl nitriles as surrogates in moderate yield ${ }^{24,25}$. Due to the lack of direct $\alpha$-arylations of cyclopropyl esters and the highest value of ester units for subsequent transformations, we sought to discover a method to accomplish this transformation.

Consistent with the prior literature 24,25 , our initial efforts to achieve the $a$-arylation of a cyclopropyl methyl ester under the conditions reported for common esters gave no coupled product 32,33 . Only the side product of Claisen condensation was observed. We considered that a $t$-butyl ester should undergo condensation less rapidly and allow formation of the enolate in higher yield. However, most $\alpha$-arylation reactions of $\alpha, \alpha-$ disubstituted esters have been conducted with esters that are less hindered than $t$-butyl esters because the steric hindrance of the $t$ butyl ester prevents reaction at the hindered $\alpha$-position ${ }^{34-36}$. It was unclear if the small ring esters would behave more like $\alpha, \alpha-$ disubstituted esters or less hindered esters.

The reaction of 4-bromo-1-fluoro-2-methoxybenzene (2a) with cyclopropyl $t$-butyl ester 1a was used to evaluate catalysts and conditions that would lead to the $\alpha$-arylation of cyclopropyl esters, and the results of these experiments are shown in Supplementary Table 1 . This reaction gave a measurable, but low, 38\% yield of coupled product 3a under the conditions reported for coupling of acyclic esters (Supplementary Table 1, entry 1). Reactions with varied ligands, bases, and temperatures gave less than $63 \%$ yield of the coupled product (Supplementary Table 1 , entry $2-12$ ).

In most cases, substantial quantities of the bromoarene remained unreacted, even though the same bromoarene is known to undergo rapid $\alpha$-arylation of enolates, including acyclic esters $^{32,33}$. We presumed the ester enolate decomposed or underwent Claisen condensation, leaving unreacted bromoarene. In this case, a higher proportion of active catalyst was needed for the rate of coupling to be higher than the rate of decomposition of the enolate. Thus, we tested alternative palladium sources and found that reactions catalyzed by the Pd precursors (Pd-4, Pd-5) recently reported by Hazari occurred to full conversion of the bromoarene (Supplementary Table 1, entry $16-17)^{37,38}$. Because a cationic metal center having a lower coordination number would be more electrophilic and susceptible to nucleophilic attack at the sacrificial ligand ${ }^{39}, \mathrm{AgBF}_{4}$ was added prior to the enolate to generate a cationic Pd complex in situ. With this further change to the method for generating the active catalyst, the $\alpha$-aryl ester was obtained in $99 \%$ isolated yield (Supplementary Table 1, entry 18).

Scope of the a-arylation of cyclopropyl esters. The scope of the $\alpha$-arylation of $t$-butyl cyclopropyl esters under the developed conditions is illustrated by the examples in Fig. 2. Aryl bromides containing a variety of functional groups at varying positions reacted with 2.0 equiv. of cyclopropyl $t$-butyl ester and 2.1 equiv. of lithium dicyclohexylamide $\left(\mathrm{LiNCy}_{2}\right)$ as base in $70-99 \%$ yield when catalyzed by $5 \%$ of Pd-5 in toluene at $65^{\circ} \mathrm{C}$ for $12 \mathrm{~h}(\mathbf{3 a}-3 \mathbf{j})$. Both strongly electron-donating (morpholine in 3d) and electronwithdrawing substituents (amide and acetal in $\mathbf{3 f}$ and $\mathbf{3 i}$, respectively) on the aryl bromides were tolerated, along with potentially coordinating thioethers $(\mathbf{3 h})$ and potentially reactive silyl ethers (3c). The coupling also occurred with aryl bromides containing polycyclic substituents, such as $\mathbf{2 k}$ and $\mathbf{2 l}$, providing $3 \mathbf{k}$ and $\mathbf{3 l}$ in $94 \%$ and $91 \%$ yield, respectively. Coupling of heteroaryl electrophiles, such as bromothiophenes, -indoles, -pyridines, -benzothiophenes, and -pyrroles occurred in $>70 \%$ yield (3m-3q). Reaction of an aryl-substituted cyclopropyl ester $\mathbf{1 r}$ gave $3 \mathbf{r}$ in $85 \%$ yield with high diastereoselectivity. Reaction of a highly substituted cyclopropyl ester, ethyl chrysanthemumate 1s, even occurred smoothly to give $64 \%$ isolated yield of the coupled product 3 s.

So far, the reactions of phenyl chloride and phenyl triflate as a representative member of these types of aryl electrophiles have not given coupled product, even though that of phenyl bromide gave the arylated product $\mathbf{3 b}$ in $92 \%$ yield. The reaction of phenyl iodide did occur to give the coupled product in $64 \%$ yield. The 12-h reaction time used for convenience when assessing reaction scope was not necessary. The arylation of cyclopropyl esters with both electron-rich and electron-poor aryl bromides (3c, 3d, 3f, 3i) afforded the coupled products after just $10 \mathrm{~min}$ in yields that were comparable to reactions conducted for the longer times.

Development of the a-arylation of cyclobutyl esters. Just one example of the direct $\alpha$-arylation of cyclobutyl methyl ester was disclosed in a patent and stated to occur in $53 \%$ yield $^{26}$. Because of the modest yield and narrow scope of this reaction, the products have been prepared with alternative reactants, such as silyl ketene acetals or nitriles ${ }^{24,25,31,40}$. However, the versatility of esters for further derivatization and the simplicity of using an ester for the coupling reaction make it important to identify conditions and catalyst for the direct $\alpha$-arylation of cyclobutyl esters.

To test the veracity and potential scope of the patented procedure ${ }^{26}$, we studied reactions of arylbromide $\mathbf{5}$ with cyclobutyl methyl ester 4a (Supplementary Table 2). However, $<30 \%$ yield of $\mathbf{6 a}$ was observed after a series of initial studies. The major products in all cases resulted from Claisen condensation of the cyclobutyl methyl ester $\mathbf{4 a}$ and hydrodehalogenation of the aryl bromide 5 .

To suppress the Claisen condensation and to avoid formation of a reducing alcohol, we tested reactions with a bulkier ester. Indeed, the reaction of cyclobutyl $t$-butyl ester $\mathbf{4 b}$ (Supplementary Figure 14) gave a much higher $76 \%$ yield of coupled product $\mathbf{6 b}$ without any detectable product from Claisen condensation. Yet, Pd-catalyzed hydrodehalogenation of aryl bromide $4 \mathbf{b}$, possibly from the a-proton of ester $\mathbf{5}$ or trace water, was still observed. Instead, reaction conducted with just $1 \%$ of indenyl complex [Pd] -5 (Supplementary Fig. 14) gave product $\mathbf{6 c}$ in $99 \%$ yield without any observed side reactions. Thus, the coupling of a $t$-butyl cyclobutyl ester with an aryl halide occurs in high yield with $1 \%$ [Pd] $-\mathbf{5}$ as catalyst, and $2 \% \mathrm{AgOTf}$ as additive in toluene at $50^{\circ} \mathrm{C}$.

Scope of $\boldsymbol{\alpha}$-arylation of cyclobutyl $\boldsymbol{t}$-butyl esters. Experiments on the scope of the $\alpha$-arylation of cyclobutyl $t$-butyl esters with a series of aryl bromides is summarized in Fig. 3. Both electron-rich and electron-poor aryl bromides underwent coupling in 81-99\% yield with $1 \mathrm{~mol} \%[\mathbf{P d}]-\mathbf{5}$. Functional groups, including aryl chlorides, acetals, sulfonamides, amides, morpholino groups, and a thioether at varying positions were all tolerated $(\mathbf{6 c}-\mathbf{6 j})$. When 1-bromo-2-methylbenzene was used as substrate, product $\mathbf{6 k}$ formed in $93 \%$ yield. Aryl halides containing more hindered ortho substituents reacted in lower yet still moderate yields with a higher catalyst loading (61-6m). The coupling of a range of heteroaryl bromides also occurred. The coupling of brominated pyridine, indole, pyrrole, thiazole, thiophene, furan and benzothiazole with $t$-butyl ester $\mathbf{4 b}$ occurred in $70 \%$ to quantitative yield $(\mathbf{6 n}-\mathbf{6 t})$. The structure of $\mathbf{6 r}$ was confirmed by X-ray crystallographic analysis.

The $\alpha$-arylation of cyclobutyl esters extends beyond reactions of the parent cyclobutyl carboxylic esters. The results in Fig. 3 show that the coupling of cyclobutyl esters containing a variety of substitution patterns on the cyclobutane ring occurred in high 


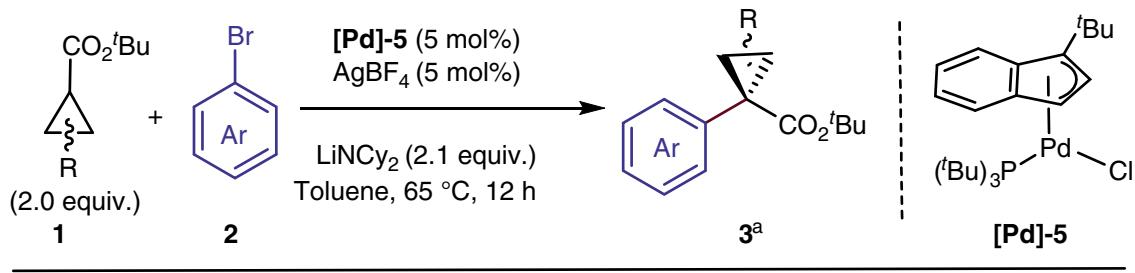<smiles>COc1cc(C2(C(=O)OC(C)(C)C)CC2)ccc1F</smiles>

3a, $99 \%$<smiles>CCC(C)(C)OC(=O)C1(c2ccc(P)cc2)CC1</smiles>

$\mathrm{R}=\mathrm{H}, \mathbf{3 b}, 92 \%{ }^{\mathrm{b}}$

OTBS, $3 \mathrm{c}, 81 \%(77 \%)^{\mathrm{C}}$<smiles>CCCCOC(=O)CCCC</smiles><smiles>CCOC(=O)C1(c2ccc(OCC)cc2)CC1</smiles>

3e, $84 \%$<smiles>CCNC(=O)c1ccc(C2(C(=O)OC(C)(C)C)CC2)cc1</smiles>

$$
\text { 3f, } 81 \%(80 \%)^{c}
$$<smiles>CCCC(=O)OC(C)(C)c1ccc(Cl)cc1</smiles>

3g, $90 \%$<smiles>CCCC(=O)C1(c2cccc(S(C)(C)C)c2)CC1</smiles><smiles>CCCOC(CCC)(c1cccc(C2OCCO2)c1)C1CC1</smiles><smiles>CCOC(=O)C1(c2ccc(OC)cc2F)CC1</smiles>

3h, $81 \%$

3i, $78 \%(77 \%)^{\mathrm{c}}$

3j, $70 \%$<smiles>COc1ccc(C2(C(=O)OC(C)(C)C)CC2)cc1[C@]12CC3C[C@@H](C[C@H](C3)C1)C2</smiles>

3k, $94 \%$<smiles>CCCC(=O)C1(c2ccc3c(ccn3C)c2)CC1</smiles>

3n, $80 \%$<smiles>CCO[C@@H]1C[C@@H]2CC[C@]1(C)C2(C)C</smiles>

3I, $91 \%$<smiles>COc1ccc(C2(C(=O)OC(C)(C)C)CC2)c(OC)n1</smiles>

3o, $71 \%$<smiles>CCOC(=O)C1(c2ccccc2)CC1</smiles><smiles>CCC(C)(C)OC(=O)C1(c2ccsc2)CC1</smiles><smiles>CCCCOC(=O)CCC</smiles>

3q, $75 \%$<smiles>CCOC(=O)[C@@]1(c2ccc(F)c(OC)c2)C[C@H]1c1ccc(C)cc1</smiles>

$3 r, 85 \%{ }^{\mathrm{e}}$
$3 m, 79 \%$<smiles>CCCC(=O)C1(c2ccc3sccc3c2)CC1</smiles>

$3 p, 72 \% d$<smiles>COc1cc([C@]2(C)[C@H](C=C(C)C)C2(C)C)ccc1F</smiles>

3s, $64 \%^{\dagger}$

Fig. 2 Scope of $\alpha$-arylation of cyclopropyl t-butyl esters. alsolated yields, dr was determined by crude ${ }^{19} \mathrm{~F} \mathrm{NMR.} \mathrm{bWith} \mathrm{PhCl}$ or $\mathrm{PhOTf}$ used instead of $\mathrm{PhBr}$, no product was observed; with Phl used instead, 64\% yield. cYield in the parentheses in $10 \mathrm{~min} . \mathrm{d}^{\mathrm{d}} \mathrm{mol} \%$ [Pd] cat and $\mathrm{AgBF}_{4}$ were used. e $50{ }^{\circ} \mathrm{C}$, dr $12: 1$, major isomer is shown. ${ }^{f}$ Major isomer is shown; $\mathrm{dr}=2: 1$. TIPS: triisopropylsilyl

yield. The increased structural complexity of the corresponding products could allow further transformations or derivatization. For example, the cyclobutyl ester containing an acetal group coupled efficiently with both aryl and heteroaryl bromides (75\% yield for $\mathbf{6 x}, 98 \%$ yield for $\mathbf{6 w}$ ). These structures serve as sources of the cyclobutanones after hydrolysis. For example, the direct hydrolysis of $\mathbf{6 x}$ gave the cyclobutanone $\mathbf{6 y}$ in $79 \%$ yield. A TBSprotected hydroxyl group was well tolerated, furnishing arylated product $6 \mathrm{v}$ in quantitative yield with $4: 1$ diastereoselectivity. A substrate containing a gem-difluoromethylene group also coupled 


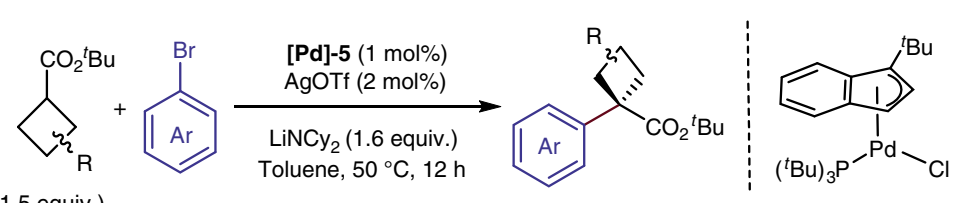

(1.5 equiv.)

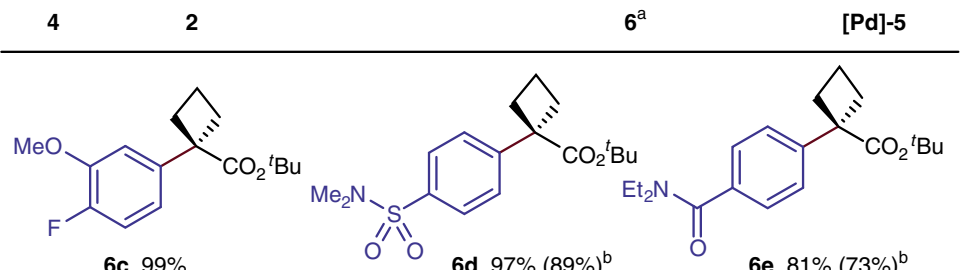

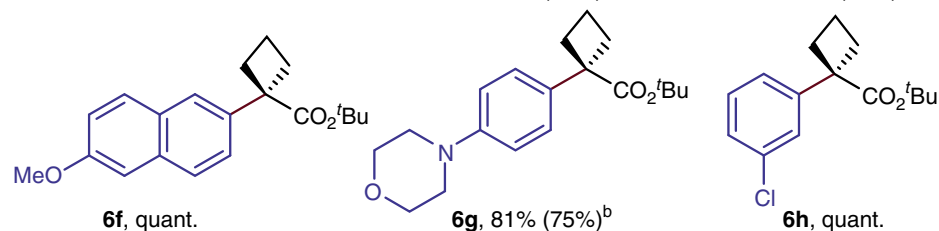<smiles>CCCC(=O)OC1(c2cccc(C3OCCO3)c2)CCC1</smiles>

6i, quant. ${ }^{\mathrm{c}}$<smiles>CCOC(=O)C1(c2cc(F)ccc2OC)CCC1</smiles>
$61,67 \%^{\mathrm{d}}$<smiles>CCOC(=O)C1(c2ccc3c(ccn3C)c2)CCC1</smiles>

6o, quant.<smiles>CCCC(=O)OC(C)(CCC)c1csc2ccccc12</smiles>

$6 r, 92 \%$<smiles>CCCOC(=O)C1(c2ccco2)CCC1</smiles>

6t, $92 \%$<smiles>CCCC(=O)C1(c2ccco2)CC2(C1)OCCO2</smiles>

6w, $98 \%{ }^{\mathrm{h}}$<smiles>CCCOC(CCC)(c1cccc(S(C)(C)C)c1)C1(C(C)(C)C)CCC1</smiles>

6j, $93 \%(90 \%)^{\mathrm{b}}$<smiles>CCCOC(=O)C1(c2ccccc2C(F)(F)F)CCC1</smiles>

$6 \mathrm{~m}, 50 \%$<smiles>CCCCCOC(=O)C1(c2cnn(C)c2)CCC1</smiles>

$6 p, 71 \%^{\mathrm{e}}$

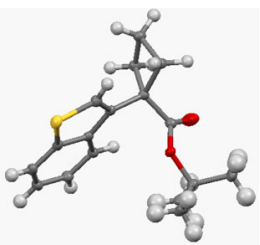

$6 r$<smiles>CCCC(=O)[C@@](CC(C)(F)F)(CC(F)(F)F)c1ccc2cc(OC)ccc2c1</smiles>

6u, quant. ${ }^{\dagger}$<smiles>CCCOC1(c2ccc(F)c(OC)c2)CC2(C1)OCCO2</smiles>

6x, $75 \%^{\mathrm{h}}$<smiles>CCCC(=O)OC1(c2ccccc2[N+](=O)[O-])CCC1</smiles>

6 k, $93 \%$<smiles>CCCOC(=O)C1(c2cccnc2Cl)CCC1</smiles>

6n, $70 \%$<smiles>CCOC(=O)C1(c2cscn2)CCC1</smiles>

$6 q, 88 \%$<smiles>CCOC(=O)C1(c2ccsc2)CCC1</smiles>

$6 s, 79 \%$<smiles>CCCCO[C@]1(c2ccc(F)c(OC)c2)C[C@@H](OCCC)C1</smiles>

$6 v$, quant. $^{9}$

Fig. 3 Scope of $\alpha$-arylation of cyclobutyl t-butyl esters. alsolated yields. bYield in the parentheses in $10 \mathrm{~min} .{ }^{\mathrm{c}} 2 \mathrm{~mol} \%$ [Pd] cat and AgOTf were used. ${ }^{\mathrm{d}} 2 \mathrm{~mol}$ $\%$ [Pd] cat was used. ${ }^{5} \mathrm{~mol} \%$ [Pd] cat was used. ${ }^{5} 5 \mathrm{~mol} \%$ [Pd] cat was used without AgOTf. 85 mol\% [Pd] cat and $\mathrm{AgBF}_{4}$ were used, dr 4:1, major isomer is shown. ${ }_{5} 5$ mol\% $[\mathrm{Pd}]$ cat and $\mathrm{AgBF}_{4}$, ester (2 equiv.), $\mathrm{LiNCy}_{2}$ (2.1 equiv.) at $65^{\circ} \mathrm{C}$ were used. i From $\mathbf{6 u}$ through hydrolysis. TBS: tert-butyldimethylsilyl 
in quantitative yield $(\mathbf{6 u})$. Again, the yields of these arylation reactions with both electron-rich and electron-poor aryl bromides after 10 min were comparable to those obtained from standard 12h reaction times $(\mathbf{6 d}, \mathbf{6 e}, \mathbf{6 g}, \mathbf{6 j})$.

Development of the $a$-arylation of azetidine $t$-butyl esters. Small saturated heterocycles are known to undergo ring opening in the presence of nucleophiles ${ }^{41,42}$, and this reactivity could interfere with the $a$-arylations of azetidine carboxylates. Consistent with this assertion, the $\alpha$-arylations of azetidine esters have been limited to a single reaction of a Cbz-protected azetidine $t$ butyl ester in a patent stated to occur in $69 \%$ yield with $16 \mathrm{~mol} \%$ [Pd] loading 27 , and even this one example has not been reproducible after extensive experimentation.

Our attempts to couple the Cbz-protected azetidine with an aryl bromide showed that reactions of the two coupling partners in the patent disclosure under conditions identical to those described gave only $17 \%$ yield of the product with $16 \mathrm{~mol} \%$ of catalyst, far less than the reported 69\% (Supplementary Table 3). Only $7 \%$ of the azetidine ester remained after $1 \mathrm{~h}$ at room temperature, indicating that the ester is unstable to the reaction conditions. The reaction of aryl bromide $\mathbf{2 a}$, with other azetidine esters containing a Boc or trifluoroacetyl group on nitrogen consumed all of the starting azetidine, but formed the coupled product in low yield. These results indicate that azetidine esters protected by electron-withdrawing groups on nitrogen are unsuitable for coupling with aryl halides with useful scope and yields under the reported conditions because they decompose, even at room temperature, in the presence of a base sufficiently strong to generate the enolate.

To achieve couplings of azetidines in high yield, we proposed that azetidines containing a less electron-withdrawing benzyl group on nitrogen should be more stable but suitable for subsequent deprotection (Supplementary Table 4). Although the reaction of Bn-protected azetidine $\mathbf{7 d}$ with lithium bis(trimethylsilyl)amide (LiHMDS) as base gave no product, $32 \%$ of $7 \mathbf{d}$ did remain unreacted after $12 \mathrm{~h}$ at $50{ }^{\circ} \mathrm{C}$, indicating that this azetidine derivative is more stable under the conditions of the a-arylation than those containing a carbonyl group on nitrogen. The reaction with $\mathrm{LiNCy}_{2}$ in place of LiHMDS gave $43 \%$ yield of product $8 \mathbf{8 o}$, and further experimentation showed that the reaction with lithium 2,2,6,6-tetramethylpiperidide (LiTMP) as base gave $88 \%$ yield of the coupled product when 1.5 equiv. of azetidine $7 \mathbf{d}$ were used. Reaction conditions that are similar to those used for the $\alpha$ arylation of cycloproyl ester gave a yield that was comparable ( $82 \%$ yield) to that from the combination of $\mathrm{Pd}(\mathrm{dba})_{2}+{ }^{t} \mathrm{Bu}_{3} \mathrm{P}$ as catalyst ( $88 \%$ yield) for the generation of compound 8o. The use of $\mathrm{Pd}\left(\mathrm{P}^{t} \mathrm{Bu}_{3}\right)_{2}$ as catalyst also gave a comparable $82 \%$ yield of product 8 .

Scope of $\boldsymbol{\alpha}$-arylation of azetidine $\boldsymbol{t}$-butyl esters. A wide range of aryl- and heteroaryl-bromides, as well as alkenyl bromides coupled with 3-t-butyl azetidine carboxylate under the developed conditions (Fig. 4). A series of functional groups at varying positions on the aryl ring were tolerated (8a-8n, 67-99\% yield). For example, aryl bromides containing electron-donating groups, such as OTBS, SMe, or morpholino groups, gave $75-99 \%$ yield of coupled product $(\mathbf{8 b}, \mathbf{8 1}, \mathbf{8 i})$; those containing electronwithdrawing groups, such as $\mathrm{CF}_{3}$, sulfonamide, amide, $\mathrm{Cl}$, and acetal, gave $78-99 \%$ yield of coupled product $(\mathbf{8 f}-\mathbf{8 h}, \mathbf{8 j}, \mathbf{8 m})$. Strongly base-sensitive groups were not tolerated, but an aryl bromide containing a $t$-butyl ester reacted in good yield (8k). Bulky substituents, like an $i$-propyl group, at the ortho-position of the aryl bromide were tolerated; ortho-isopropyl product $8 \mathbf{n}$ formed in $81 \%$ isolated yield. Multi-substituted aryl bromides also reacted with the $t$-butyl azetidine carboxylate to give the coupled product in $76-89 \%$ yields $(\mathbf{8 o - 8 q})$. The reaction of a half-gram of bromide 2a with 3-t-butyl azetidine carboxylate occurred in a yield that was comparable with that on a smaller scale $(\mathbf{8 o}, 85 \%$ for half-gram scale vs $88 \%$ for $0.1 \mathrm{mmol}$ scale).

Additional $\mathrm{sp}^{2}$ carbon electrophiles also reacted with the azetidine ester. For example, the alkenyl bromide trans- $\beta$ bromostyrene or 1-bromo-2-methylprop-1-ene reacted with 3tert-butyl azetidine carboxylate to give the coupled product $8 \mathbf{r}$ and $8 \mathrm{~s}$ in $84 \%$ and $86 \%$ yield, respectively. Likewise, a series of heteroaryl bromides coupled in high yield. For example, coupling of 3-t-butyl azetidine $\mathbf{7 d}$ with a bromo-pyridine, -indole, -pyrrole and -quinoline all occurred in $74-96 \%$ yield $(\mathbf{8 t}-\mathbf{8 w})$.

In contrast to the $a$-arylation of small carbocycles, the $\alpha$ arylation of $t$-butyl azetidine carboxylate occurred with phenyl chloride, affording the arylated product $8 \mathbf{a}$ in a moderate $40 \%$ yield under the standard reaction conditions without further optimization. For comparison, the reaction of phenyl bromide and iodide occurred in $99 \%$ and $70 \%$ yield respectively. Similar to the $\alpha$-arylation of small carbocycles, the $\alpha$-arylation of $t$-butyl azetidine carboxylate with phenyl triflate did not occur. The reactions of $t$-butyl azetidine carboxylate with both electron-rich and electron-poor aryl bromides $\mathbf{8 b}, \mathbf{8 f}-\mathbf{8 i}$, and $\mathbf{8 0}$ occurred to completion in $10 \mathrm{~min}$, giving yields of coupled product that were comparable to those obtained after $12 \mathrm{~h}$.

Debenzylation-alkylation of the $\boldsymbol{\alpha}$-aryl azetidine product. The value of the $N$-benzyl azetidine products rests upon removal of the benzyl group. Thus, procedures were developed to remove or replace this group, and these studies revealed an unusual alkylation of the azetidine under typical conditions for hydrogenolysis of an $N$-benzyl group ${ }^{43}$. Initial experiments to identify conditions for cleavage of the $N$-benzyl group by classical procedures with $\mathrm{Pd} / \mathrm{C}$ as catalyst, $\mathrm{H}_{2}$ as reagent and $\mathrm{MeOH}$ as solvent gave no $\mathrm{N}-\mathrm{H}$ azetidine; instead, the corresponding $\mathrm{N}$-methyl azetidine 9a was obtained in $70 \%$ yield (Supplementary Fig. 18). The same reaction of three additional $\mathrm{N}$-benzyl aziridines gave the analogous methylated azetidines in good yield (9b-9d).

To assess the applicability of this reaction to the formation of other $\mathrm{N}$-alkyl aziridines, we conducted the debenzylation in a series of alcohols. The reaction in ethanol gave the ethylated azetidine $9 \mathbf{e}$ in $84 \%$ yield, and the reaction in $i$-propanol gave the $N$-isopropyl product 9 in a moderate $62 \%$ yield. The same process with cyclopropylmethanol led to reductive ring-opening, followed by alkylation of the azetidine to give $\mathbf{9 g}$ in $50 \%$ yield. Discussion of the mechanism of these processes can be found in Supplementary Fig. 19 and accompanying legend.

Derivatizations of $\boldsymbol{N}$-benzyl azetidines. Although this alkylation of the azetidine during hydrogenolysis of the $N$-benzyl linkage can be useful for installation of simple alkyl groups, a method was sought to form an azetidine with a conventional carbamate group that would allow for more diverse subsequent transformations. Fortunately, the alkylation process could be interrupted with an anhydride to capture the free azetidine. As shown in Fig. 5, hydrogenolysis of the $N$-benzyl group in the presence of carboxylic acid anhydrides led to the acylated azetidines. The carbamate, acetamide, and longer chain amides 10-12 were isolated in high yields (81-89\%).

The Boc-protected azetidine proved to be a valuable precursor to the free amine as a synthetic intermediate. For example, the $\mathrm{N}$ aryl azetidine $\mathbf{1 4}$ was obtained by cleaving the Boc group to form the free azetidine and conducting a palladium-catalyzed cross 


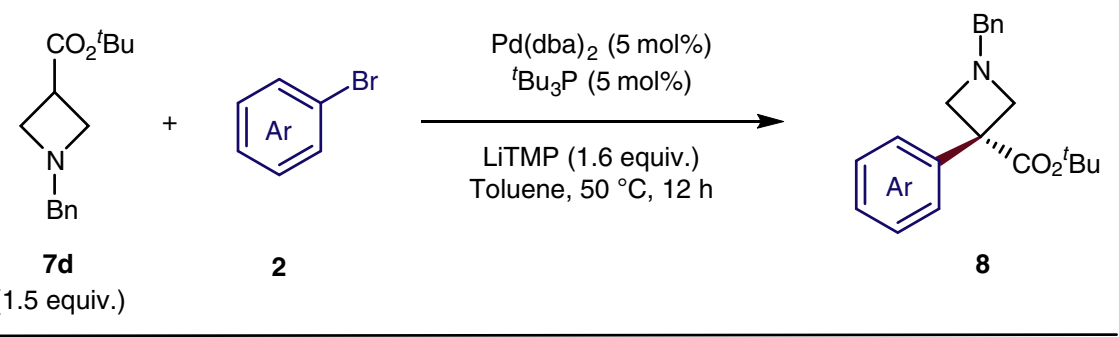<smiles>[R]OC1(c2ccc(Br)cc2)CN(Cc2ccccc2)C1</smiles>
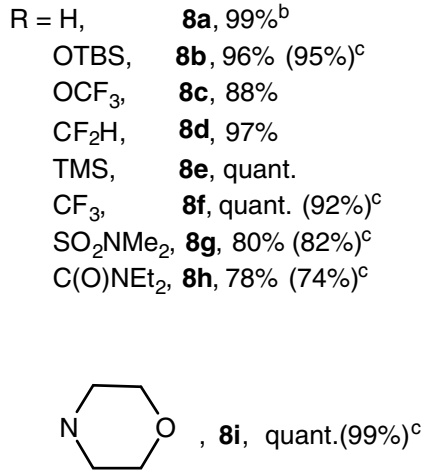<smiles>[R]c1cccc(C2(C(=O)OCC)CN(Cc3ccccc3)C2)c1</smiles>

$$
\begin{array}{r}
\mathrm{R}=\mathrm{Cl}, \quad \mathbf{8 j}, \quad 78 \% \\
\mathrm{CO}_{2}{ }^{{ } \mathrm{Bu},} \mathbf{8 k}, 67 \% \\
\mathrm{SMe}, \quad \mathbf{8 I}, \quad 75 \%
\end{array}
$$<smiles>CCOCC1(c2ccccc2C(C)C)CN(Cc2ccccc2)C1</smiles>

$8 n, 81 \%^{d}$<smiles>C[As](O)(Br)C1OCCO1</smiles><smiles>CCCOC1(c2ccc3c(c2)OC(F)(F)O3)CN(Cc2ccccc2)C1</smiles>

$8 p, 76 \%$<smiles>[R7]C([R16])=CC1(C(=O)OCCC)CN(Cc2ccc([C@]3(C(=O)OCc4ccccc4)CCC3(C)C)cc2OC)C1</smiles><smiles>CCOC(=O)C1(c2ccc(OC)c([C@]34C[C@@H](C)C[C@@H](C[C@H](C)C3)C4)c2)CN(Cc2ccccc2)C1</smiles>
$\mathrm{R}^{1}=\mathrm{H}, \mathrm{R}^{2}=\mathrm{Ph}, \mathbf{8 r}, 84 \%$ $8 \mathbf{q}, 89 \%$ $R^{1}, R^{2}=M e, 8 s, 86 \%$<smiles>CCCOC(=O)C1(c2ccc(S(C)(C)C)nc2)CN(Cc2ccccc2)C1</smiles><smiles>CCC(C)OC(=O)C1(c2ccn(C(C)C)c2)CN(Cc2ccccc2)C1</smiles>

$8 v, 75 \%$<smiles>CCCOC(=O)C1(c2ccc3ncccc3c2)CN(Cc2ccccc2)C1</smiles>

$8 w, 74 \%{ }^{\dagger}$

Fig. 4 Scope of $\alpha$-arylation of azetidinyl t-butyl esters. alsolated yields. bFor $\mathrm{PhCl}$ use instead, $40 \%$ yield; For Phl used instead, $70 \%$ yield; For PhOTf used instead, no product. CYield shown in the parentheses after $10 \mathrm{~min} .{ }^{\mathrm{d}} \mathbf{7 d}$ (2.0 equiv.), LiTMP (2.1 equiv.), [Pd] (10 mol\%), ${ }^{\mathrm{B}} \mathrm{Bu} \mathrm{H}_{3} \mathrm{P}(10 \mathrm{~mol} \%)$ were used instead. eHalf-gram scale test gave $85 \%$ yield. ${ }^{\mathbf{f}} \mathbf{7 d}$ (2.0 equiv.), LiTMP (2.1 equiv.) were used instead

coupling of the resulting amine with an aryl halide. The combination of acid-catalyzed cleavage of the $N$-Boc linkage and acylation with benzoyl chloride gave the $N$-benzoyl azetidine 16, whereas cleavage and reductive amination with cyclopropanecarbaldehyde gave the $N$-cyclopropylmethyl azetidine 17 . Overall, the combination of $\alpha$-arylation, conversion of the $t$-butyl ester to any of the functional groups accessible from an ester, and derivatization of the free nitrogen after deprotection generates an azetidine core containing a wide range of substituents at three positions.
Application to biologically relevant molecules. To illustrate the synthetic potential of these $\alpha$-arylations of small rings, we prepared three biologically relevant molecules by short sequences that include an $\alpha$-arylation (Fig. 6). The commercial drug and CFTR corrector Lumacaftor illustrates the value of the $a$-arylation of a cyclopropane ${ }^{9}$. The reported synthesis required four steps to reach the key intermediate 18. Our method afforded 18 in high yield over just two steps (Fig. 6a) ${ }^{44}$. The analog 20 of Etofenprox, studied for potential insecticidal activity illustrates the value of the $\alpha$-arylation of a cyclobutane. Sequential $\alpha$-arylation, 
<smiles>COc1cc(C2(C(=O)OCC(C)(C)C)CN(C(C)=O)C2)ccc1F</smiles><smiles>CCOC(=O)c1cccc(C2(c3cccc(OC(C)(C)C)c3)CN(Cc3ccccc3)C2)c1</smiles><smiles>CCOC1(c2ccccc2)CN(c2ccc3ccccc3c2)C1</smiles>

14

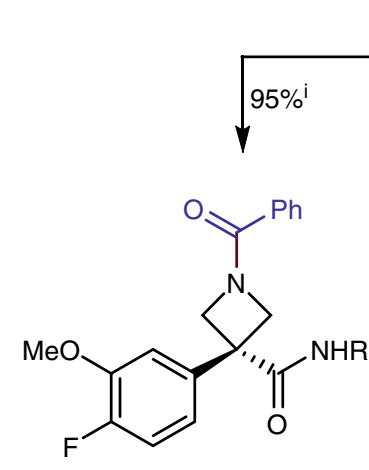

16

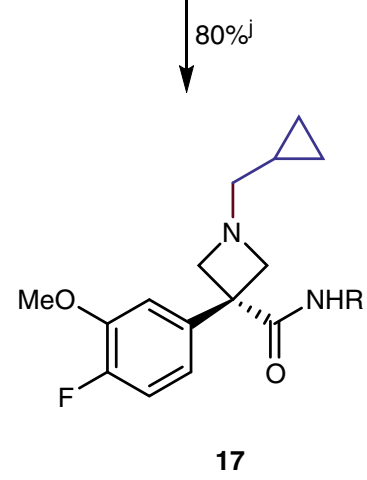

17

Fig. 5 Derivatizations of arylated azetidine products. apd $(\mathrm{OH})_{2} / \mathrm{C}, \mathrm{Boc}_{2} \mathrm{O}, \mathrm{MeOH}, \mathrm{H}_{2}, \mathrm{RT}$. bPd $(\mathrm{OH})_{2} / \mathrm{C}, \mathrm{Ac}_{2} \mathrm{O}, \mathrm{MeOH}, \mathrm{H} 2, \mathrm{RT}$. ${ }^{\mathrm{cPd}}(\mathrm{OH})_{2} / \mathrm{C}$, hexanoic anhydride, $\mathrm{MeOH}, \mathrm{H}_{2}$, RT. dStep 1: $\mathrm{HCl}$ dioxane, RT. Step 2: (COCl) $2, \mathrm{DMF}_{2} \mathrm{CH}_{2} \mathrm{Cl}_{2} / \mathrm{EtOH}, \mathrm{RT}$. ePd(OH) $/ \mathrm{CC}_{2} \mathrm{Boc}_{2} \mathrm{O}, \mathrm{H}_{2}, \mathrm{MeOH}, \mathrm{RT}$. fStep 1: TFA/ CH $\mathrm{Cl}_{2}$, RT. Step 2: 2-bromonaphthalene, $\mathrm{Pd}_{2}(\mathrm{dba})_{3}$, Xantphos, $\mathrm{Cs}_{2} \mathrm{CO}_{3}$, dioxane, $100{ }^{\circ} \mathrm{C}$. gStep 1: HCl-dioxane, RT. Step 2: 2-(4-methoxyphenyl)ethan-1-amine,

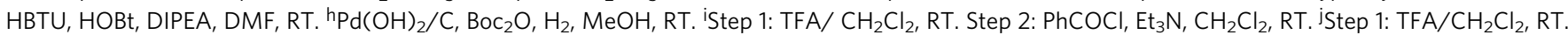
Step 2: cyclopropanecarbaldehyde, $\mathrm{Na}(\mathrm{AcO})_{3} \mathrm{BH}, \mathrm{CH}_{2} \mathrm{Cl}_{2}$, RT

reduction, and nucleophilic substitution reactions gave 20 in $87 \%$ overall yield (Fig. 6b) ${ }^{45}$. Likewise, preparation of compound 21, an analog of the commercial pain medication named Demerol ${ }^{46}$, illustrated one value of the $\alpha$-arylation of an azetidine. Compound $\mathbf{2 1}$ was easily prepared from $\alpha$-arylation product $\mathbf{8 a}$ by ester exchange and the one-step debenzylation-methylation reaction (Fig. 6c).

Preliminary mechanistic studies. Because reproducible, highyield $\alpha$-arylation reactions of the small-ring carboxylic acids had not been reported previously, we conducted a series of mechanistic experiments to reveal more clearly the reaction parameters that led to the successful development of these reactions. We first compared the relative rates of reactions of the esters containing different ring sizes. To do so, we conducted the reactions of the cyclopropyl ester 1a, cyclobutyl ester $\mathbf{4 b}$, and cyclohexyl ester $\mathbf{2 2}$ (Fig. 7a) in the same vessel. The yield of the a-arylation of cyclobutyl ester $\mathbf{4 b}$ was twice that of cyclohexyl ester 22, and only trace amounts of product from arylation of cyclopropyl ester 1a were detected. This trend in reactivity (cyclobutyl > cyclohexyl > cyclopropyl ester) was also observed from a pairwise competition of the cyclohexyl ester with substituted, small-ring carboxylic acid esters. The reaction of 4-bromo-1-fluoro-2-methoxybenzene 2a with the combination of the substituted cyclopropane $1 \mathrm{~s}$ and cyclohexane carboxylate $\mathbf{2 2}$ gave the cyclopropyl product $3 \mathrm{~s}$ in $14 \%$ yield and the cyclohexyl product $\mathbf{2 3}$ in $62 \%$ yield; the arylation of the combination of siloxy-substituted $\mathbf{4 v}$ and 22 gave cyclobutyl product $\mathbf{6 v}$ in $46 \%$ yield and cyclohexyl product 23 in $30 \%$ yield. Thus, the relative reactivity observed for the parent ring systems translated to substituted versions of the carbocyclic esters.

Previously, our group showed that a series of arylpalladium enolates underwent reductive elimination with nearly identical rates ${ }^{47}$. This result implies that the trend in reactivity of the different sizes of carbocyclic esters more likely reflects the trend in stability of the corresponding enolates than the reactivity of the palladium enolates ${ }^{23}$. H/D exchange experiments were conducted to test this hypothesis. The relative propensities of the cyclopropyl, cyclobutyl, and cyclohexyl carboxylic esters to undergo deprotonation were assessed by addition of limiting base to an excess of two esters, followed by quenching with $\mathrm{CD}_{3} \mathrm{OD}$. This experiment with equimolar amounts of $\mathrm{LiNCy}_{2}$, cyclohexyl ester $\mathbf{2 2}$ and cyclopropyl ester $\mathbf{1 s}$ at room temperature in a glovebox, gave the deuterated cyclohexyl ester 22- $d$ in $35 \%$ yield and no detectable deuterated cyclopropyl ester $1 \mathrm{~s}-d$ (Fig. $7 \mathrm{~b}$ ). The same experiment conducted with cyclohexyl ester 22 and 
a

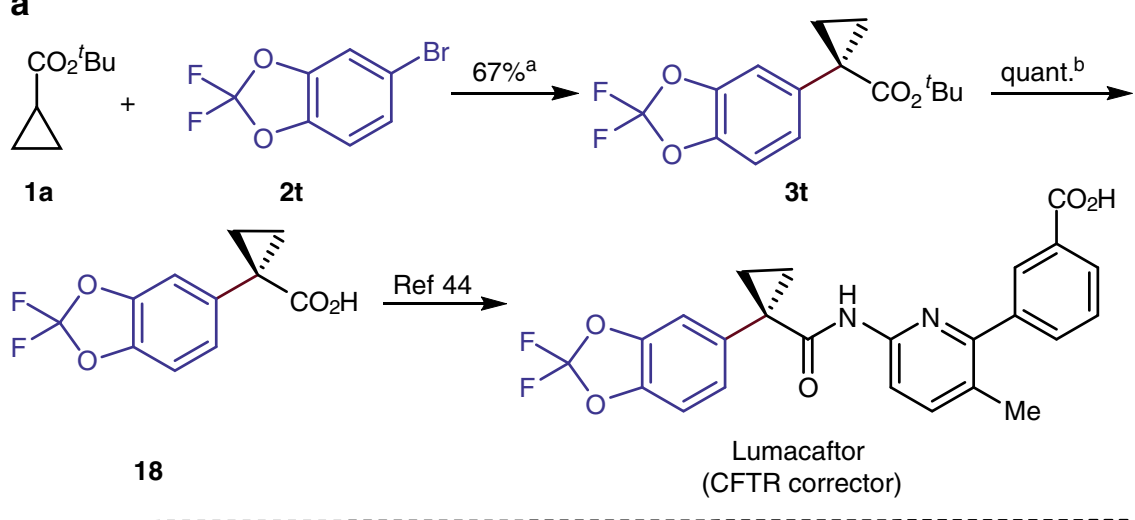<smiles>CCOc1ccc(C2(c3cc(C4(CO)CC(F)(F)C4)ccc3OCC)CC(F)(F)C2)cc1</smiles>

Fig. 6 Applications to biologically relevant molecules. a Synthesis of Lumacaftor. b Synthesis of Etofenprox analog. c Synthesis of Demerol analog. aStandard condition as shown in Fig. 2 without using $\mathrm{AgBF}_{4}$. ${ }^{\mathrm{b}} \mathrm{TFA}, \mathrm{Et}_{3} \mathrm{SiH}_{1} \mathrm{CH}_{2} \mathrm{Cl}_{2}, \mathrm{RT}$. ${ }^{\mathrm{C} S t a n d a r d}$ condition as shown in Fig. 3 without using AgOTf. $\mathrm{d}_{\mathrm{LiAlH}}, \mathrm{Et}_{2} \mathrm{O}, \mathrm{O}{ }^{\circ} \mathrm{C}-\mathrm{RT}$. eNaH, 1-(bromomethyl)-3-phenoxybenzene, THF, $0{ }^{\circ} \mathrm{C}-\mathrm{RT}$. fStep 1: HCl-dioxane, RT. Step 2: $\left(\mathrm{COCl}_{2}, \mathrm{DMF} \mathrm{CH} \mathrm{Cl}_{2} / \mathrm{EtOH}, \mathrm{RT}\right.$. gPd/C, $\mathrm{H}_{2}, \mathrm{CH}_{3} \mathrm{OH}, \mathrm{RT}$. quant.: quantative

cyclobutyl ester $\mathbf{4 v}$ gave more deuterated cyclobutyl ester $\mathbf{4 v}-d$ (40\%) than cyclohexyl ester 22-d (6\%). These results imply that the rate or equilibrium for deprotonation of these enolates follows the order: cyclobutyl $>$ cyclohexyl $>$ cyclopropyl. This order reflects their corresponding acidity and matches the order of reactivity toward the $\alpha$-arylation described above. Thus, the low acidity of the cyclopropyl ester is one property of this ester that makes its coupling reactions challenging.

Additional experiments revealed the effect of the ring size on the rates of transmetallation of the ester enolates (Fig. 8). Three different $O$-bound lithium enolates ${ }^{48}$ were generated in situ separately from 1 equiv. of $t$-butyl ester (1a, or $\mathbf{4 b}$, or 22$)$ and a slight excess of $\mathrm{LiNCy}_{2}$ in toluene for $15 \mathrm{~min}$. Reaction of a mixture of the three enolates with 1 equiv. of aryl bromide $\mathbf{2 a}$ and $5 \mathrm{~mol} \%$ catalyst at $65^{\circ} \mathrm{C}$ for $6 \mathrm{~h}$ formed the products from cyclopropane and cyclobutane in $47 \%$ and $34 \%$ yield, respectively, and only $13 \%$ of the product from the cyclohexyl ester (Fig. 8a). This trend was corroborated by similar reactions of aryl bromide 2a with enolates generated from cyclopropyl ester $\mathbf{1 a}$ and cyclohexyl ester 22, which gave the corresponding products in $60 \%$ and $32 \%$ yield respectively (Fig. 8 b), and by reactions of $2 \mathbf{a}$ with enolates from cyclobutyl ester $\mathbf{4 b}$ and cyclohexyl ester $\mathbf{2 2}$, which gave the corresponding products in $61 \%$ and $33 \%$ yield, respectively (Fig. 8c). Even the reaction of the less hindered enolate from the cyclohexyl methyl ester 24, instead of that from the cyclohexyl $t$-butyl ester 22, formed less of the product from this ester $(25 \%)$ than that from the enolates of the smaller-ring esters (Fig. 8d, 43\% and 29\%).

Single-turnover experiments involving the reaction of the lithium enolates with the arylpalladium complex 26 were also conducted to obtain direct information on the rates of transmetallation. Like the catalytic reactions, these reactions of the isolated arylpalladium halide complex with the combination of the lithium enolates from the three esters formed the products of the small ring esters in larger amounts than the products from the larger-ring ester (Fig. 8e). 
a Competition experiments

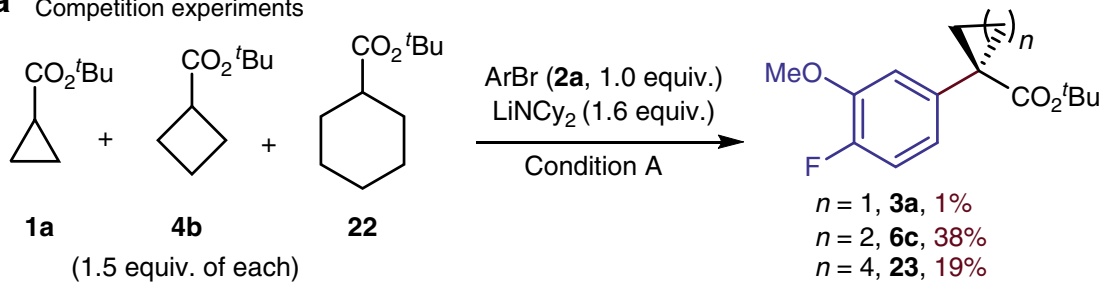<smiles>CCCCOC(=O)C1C(C=C(C)C)C1(C)C</smiles>

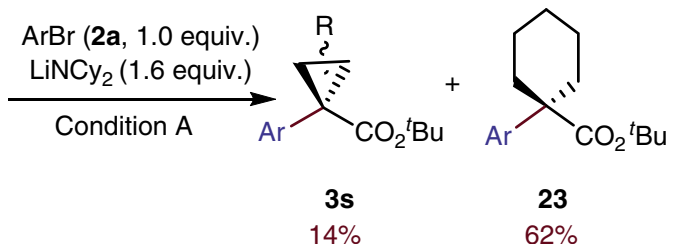<smiles></smiles>

$4 v^{\mathrm{a}}$

(1.5 equiv. of each)<smiles>CCCCC(=O)C1CCCCC1</smiles>

22

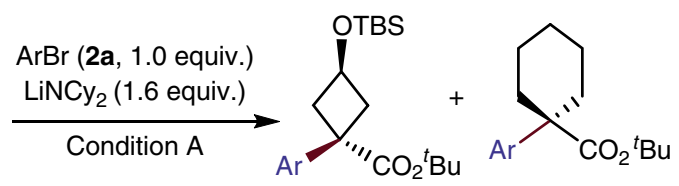

$6 \mathbf{v}^{\mathrm{b}} \quad 23$

b $\mathrm{H} / \mathrm{D}$ exchange studies<smiles>CCCCC(=O)C1[C@H](C=C(C)C)C1(C)C</smiles>

$1 s$<smiles>CCC(CC)C(=O)OCCCCCC(C)C</smiles>

Then $\mathrm{CD}_{3} \mathrm{OD}$

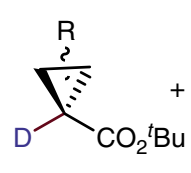

$1 s-d$ Not detected<smiles>[2H]C1(C(=O)OC(C)(C)C)CCCCC1</smiles>

22- $d$<smiles>O=C(O)CCCCCOC(=O)C1CC([SeH2])C1</smiles>

$4 v^{\mathrm{a}}$

(1.0 equiv. of each)

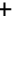$$
\text { 更 }
$$

22<smiles>CC(C)(C)OC(=O)C1CCCCC1</smiles>

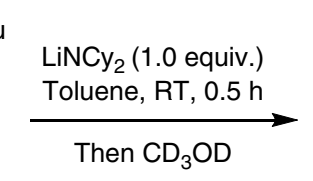

Then $\mathrm{CD}_{3} \mathrm{OD}$

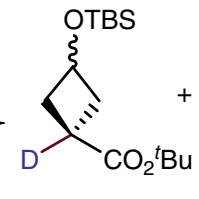

$4 \mathbf{v}-d^{\mathrm{a}}$

Fig. 7 Competition experiments and H/D exchange studies. a Competition experiments. b H/D exchange studies. Condition A: 4-bromo-1-fluoro-2methoxybenzene (2a, 1.0 equiv.), [Pd]-5 (5 mol\%), $\mathrm{AgBF}_{4}(5 \mathrm{~mol} \%), \mathrm{LiNCy}_{2}\left(1.6\right.$ equiv.), toluene, $50{ }^{\circ} \mathrm{C}, 12 \mathrm{~h}$. ${ }^{\mathrm{a}}$ Mixtures of two isomers, dr $9: 1 .{ }^{\mathrm{b}} \mathrm{Major}$ isomer is shown, dr 3:1

The final set of experiments on the mechanism of the coupling of the small-ring carbocycles involved assessing the stability of the esters in the presence of the bases and solvents that are typically used to generate the enolates during the $a$-arylation reactions. As noted in the introduction, prior $\alpha$-arylations of $\alpha, \alpha$-disubstituted esters required the smaller methyl ester, rather than the larger $t$ butyl ester. Thus, we tested the stabilities of the methyl and $t$ butyl versions of the cyclic esters in this study. The esters can decompose in the presence of base by Claisen condensation or formation of ketene.

Two equiv. of the methyl esters and one equiv. of base in toluene- $d_{8}$ were mixed at RT for $15 \mathrm{~min}$ and then quenched with an excess of methanol (Fig. 9a). Cyclopropyl methyl ester 1t was recovered in $45 \%$ yield, along with $33 \%$ of side product 27 from condensation. Cyclobutyl methyl ester $4 \mathbf{a}$ was recovered in an even lower $34 \%$ yield, with a higher $46 \%$ yield of side product $\mathbf{2 8}$ from condensation. In contrast, cyclohexyl methyl ester $\mathbf{2 4}$ was recovered in $80 \%$ yield. These data show that the methyl esters of small carbocycles are sensitive to base and are not well suited for direct $a$-arylation.

The same experiments of the $t$-butyl esters showed stabilities that matched with the difficulty in identifying conditions for the coupling reactions (Fig. 9b). Only $50 \%$ of the cyclopropyl $t$-butyl ester la was recovered by quenching of the enolate after the same $15 \mathrm{~min}$ at room temperature; the other $50 \%$ of the material was product 29 formed from condensation of the ester. This observation underscores the propensity of cyclopropyl esters to undergo condensation under the conditions of the coupling process and why the reaction required the most efficient generation of a highly active catalyst. In contrast, cyclobutyl $t$ butyl ester $\mathbf{4 b}$ was recovered in a high $92 \%$ yield from the same experiment, implying that reactions of cyclobutyl $t$-butyl esters are more forgiving than those of the cyclopropyl esters. As expected, the cyclohexyl $t$-butyl ester was fully recovered.

The same type of experiment with a mixture of the two esters was consistent with the stability of the individual esters (Fig. 9c). 
a<smiles></smiles><smiles>[R]OC(=O)[Ba][Ba]</smiles><smiles>CCOC(=O)C(C)(C)c1ccc(F)c(OC)c1</smiles>

1 equiv.

(Generated from 1a,4 b, 22 in situ seperately)

$n=1,3 \mathbf{a}, 47 \%$

$n=2,6 \mathbf{c}, 34 \%$

$n=4,23,13 \%$

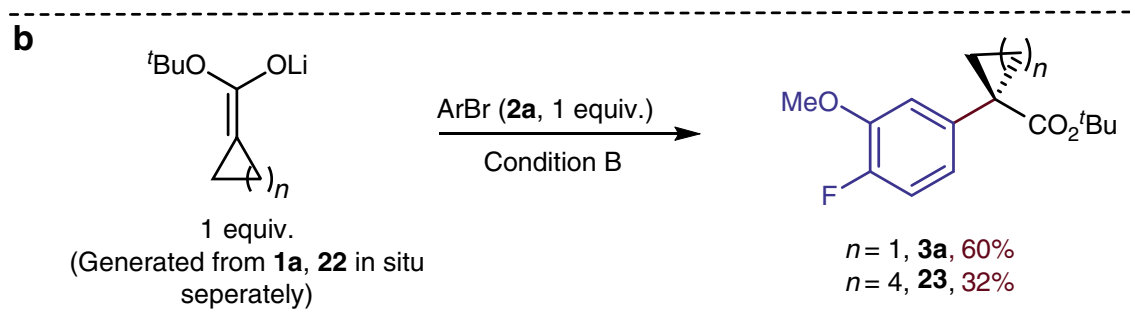

$\begin{gathered}1 \text { equiv. } \\ \text { (Generated from } \mathbf{4 b}, \mathbf{2 2} \text { in situ } \\ \text { seperately) }\end{gathered}$
Condition $\mathrm{B}$<smiles></smiles>

1 equiv. ( $m=1$ or 2 ) (Generated from 1a, $\mathbf{4 b}$ in situ seperately)

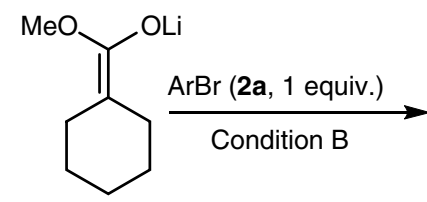

1 equiv.

(Generated from 24 in situ)<smiles>[R]C(=O)C1(C(C)(C)c2ccc(F)c(OC)c2)CC1</smiles>

$n=1, \mathrm{R}={ }^{t} \mathrm{Bu}, 3 \mathrm{a}, 43 \%$

$n=2, \mathrm{R}={ }^{t} \mathrm{Bu}, \mathbf{6 c}, 29 \%$

$n=4, \mathrm{R}=\mathrm{Me}, 25,25 \%$<smiles>COc1cc(C(C)(C)C(C)(C)C)ccc1F</smiles>

Fig. 8 Studies on transmetallation. a Competition experiments among enolates of cyclopropyl, cyclobutyl and cyclohexyl t-butyl esters. b Competition experiments among enolates of cyclopropyl, and cyclohexyl $t$-butyl esters. c Competition experiments among enolates of cyclobutyl and cyclohexyl $t$-butyl esters. d Competition experiments among enolates of cyclopropyl, cyclobutyl $t$-butyl esters and cyclohexyl methyl esters. e Competition experiments among enolates of cyclopropyl, cyclobutyl and cyclohexyl $t$-butyl esters with $\mathbf{2 6}$ as catalyst. Condition B: ester (19a, or $\mathbf{4 b}$, or $\mathbf{2 2}$, or $\mathbf{2 4}, 1$ equiv.) with LiNCy 2 (1.05 equiv.) and toluene, 4-bromo-1-fluoro-2-methoxybenzene (2a, 1 equiv.), [Pd]-5 (5 mol\%), $\mathrm{AgBF}_{4}(5 \mathrm{~mol} \%)$ at $65^{\circ} \mathrm{C}$ for $6 \mathrm{~h}$. Condition C: ester (1aa, or $\mathbf{4 b}$, or 22, 1 equiv.) with $\mathrm{LiNCy}_{2}\left(1.05\right.$ equiv.) and toluene, $\mathbf{2 6}$ (1 equiv.) at $65^{\circ} \mathrm{C}$ for $6 \mathrm{~h}$

In these mixtures, the cyclopropyl methyl and $t$-butyl esters were the least stable (70\% remaining of methyl ester $1 \mathbf{t}, 78 \%$ of the $t$ butyl ester 1a). The cyclobutyl $t$-butyl ester was almost completely stable ( $96 \%$ of $\mathbf{4 b}$ recovered), but the cyclobutyl methyl ester was unstable (38\% of $4 \mathbf{a}$ recovered); Both the cyclohexyl methyl and cyclohexyl $t$-butyl esters were relatively stable (over $90 \%$ of each was recovered).

Related experiments with the azetidine carboxylic ester showed the importance of electron-donating protecting groups on the nitrogen (Fig. 10). When the azetidine bears an electronwithdrawing acyl or carbamoyl group on nitrogen, it is unstable to the basic conditions, presumably by a process involving ring opening. For example, when the azetidine ester was mixed with $\mathrm{LiNCy}_{2}$ in toluene at RT for $20 \mathrm{~min}$, azetidines $7 \mathbf{a}-7 \mathrm{c}$ containing a carbonyl group on nitrogen were recovered in less than $39 \%$ yield while $\mathrm{Bn}$-protected azetidine $(\mathbf{7 d}$ ) was recovered in $85 \%$ yield (Fig. 10, condition D). Similar results were observed with the LiTMP base that we used in the reaction conditions to obtain the highest yields of the product from $a$-arylation of azetidine. The combination of the azetidine carboxylic ester $\mathbf{7 d}$ containing a more electron-donating Bn group as the protecting group and the LiTMP base led to $74 \%$ recovery of the azetidine. In contrast, the 


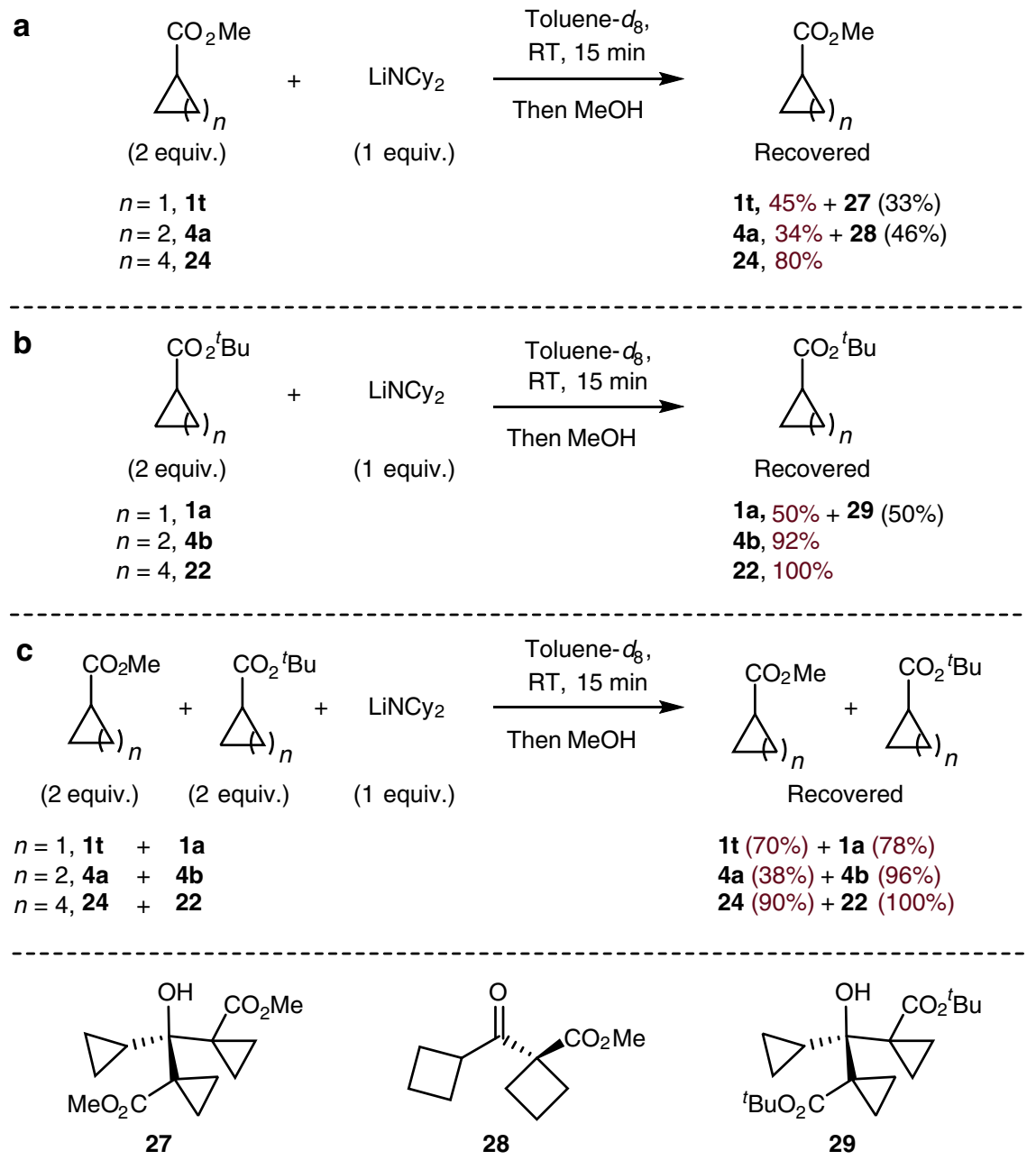

Fig. 9 Relative rates for Claisen condensation. a Claisen condensation test for cyclopropyl, cyclobutyl or cyclohexyl methyl esters individually. b Claisen condensation test for cyclopropyl, cyclobutyl or cyclohexyl $t$-butyl esters individually. c Claisen condensation test between methyl ester and related $t$ butyl ester

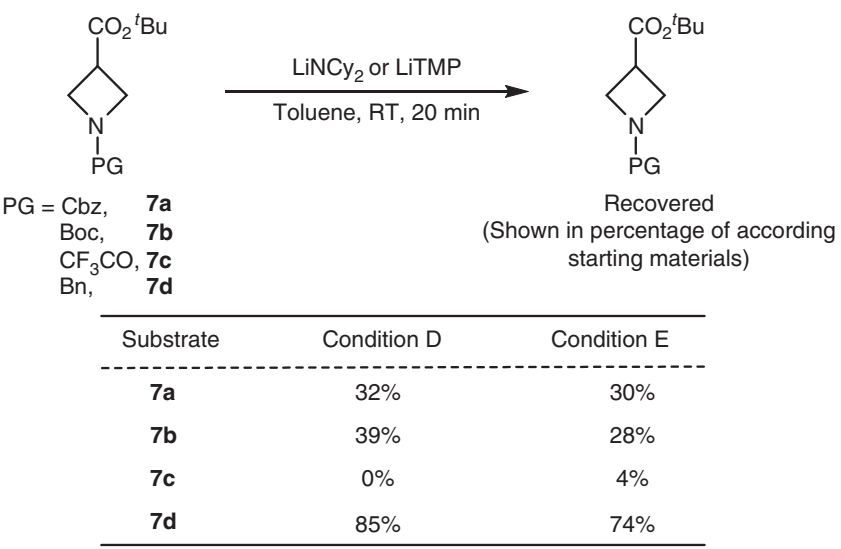

Fig. 10 Stability of different azetidine esters. Condition D: PG-azetidine (1 equiv.), LiNCy 2 (2 equiv.), toluene, RT, 20 min. Then $\mathrm{MeOH}$; Condition E: PG-azetidine (1 equiv.), LiTMP (1.05 equiv.), toluene, RT, 20 min. Then $\mathrm{MeOH}$. PG: protecting group

same experiment with $7 \mathbf{a}-7 \mathbf{c}$ containing electron-withdrawing protecting groups led to less than $30 \%$ recovery of the azetidine (Fig. 10, condition E).

These data showing the instability of the cyclopropyl ester, the cyclobutyl methyl ester, and the azetidines containing carbonyl groups on nitrogen help explain the absence of these $a$-arylation reactions in prior literature. To achieve these coupling reactions, the coupling should be conducted with a $t$-butyl ester of cyclopropane and cyclobutane and an $\mathrm{N}$-alkyl azetidine, and they should be conducted with catalysts that are sufficiently reactive to form the coupled product with a rate that exceeds that of the decomposition of the ester and competing Claisen condensation. Overall, these data highlight the challenge of coupling small ring esters and why highly active catalysts and substituents that minimize decomposition are necessary.

\section{Discussion}

In summary, systems and conditions have been identified for broadly applicable, direct $\alpha$-arylation of aromatic and heteroaromatic electrophiles with small ring esters, including cyclopropyl esters, cyclobutyl esters and azetidine esters. All three classes of arylations occurred in yields up to $99 \%$. Mechanistic studies indicate that the weak acidity of the a C-H bond in cyclopropyl esters, strong sensitivity of the strained esters to Claisen condensation, particularly for cyclobutyl esters, and facile decomposition of the enolates of azetidinyl esters were the major challenges we overcame when developing these couplings with small ring esters. Deprotection of the $N$-benzyl group led to an interesting debenzylation-alkylation process of the arylated azetidine. The reliability and generality of this coupling method were 
showcased by three short syntheses of biologically relevant molecules. Further studies on the coupling of small-ring enolates are in progress.

\section{Methods}

General procedure for $\alpha$-arylations of cyclopropyl esters. In a dry and $\mathrm{N}_{2}$-filled glovebox, the small ring ester $1(0.20 \mathrm{mmol})$ in toluene $(0.3 \mathrm{~mL})$ was added dropwise at room temperature to a $4-\mathrm{mL}$ vial containing solid $\mathrm{LiNCy}_{2}(39 \mathrm{mg}$ $0.21 \mathrm{mmol}$ ). The resulting mixture was allowed to stir for $15 \mathrm{~min}$ at RT. To a second vial containing $[\mathbf{P d}]-\mathbf{5}(2.6 \mathrm{mg}, 0.0050 \mathrm{mmol})$ and $\mathrm{AgBF}_{4}(1.0 \mathrm{mg}, 0.0050$ mmol) were added aryl bromide $2(0.10 \mathrm{mmol})$ and toluene $(0.1 \mathrm{~mL})$. The resulting mixture was shaken by hand for $30 \mathrm{~s}$. Then, the solutions in these two vials above were combined. The vial was sealed with a PTFE-lined cap, removed from the dry box, and stirred at $65^{\circ} \mathrm{C}$ for $12 \mathrm{~h}$. The reaction solution was condensed and purified by flash column chromatography to afford the pure product 3 .

General procedure for $\alpha$-arylations of cyclobutyl esters. In a dry and $\mathrm{N}_{2}$-filled glovebox, the small ring ester $4(0.15 \mathrm{mmol})$ in toluene $(0.3 \mathrm{~mL})$ was added dropwise at room temperature to a $4-\mathrm{mL}$ vial containing solid $\mathrm{LiNCy}_{2}(30 \mathrm{mg}$ $0.16 \mathrm{mmol})$. The resulting mixture was allowed to stir for $15 \mathrm{~min}$ at RT. To a second vial containing $[\mathbf{P d}]-\mathbf{5}(0.5 \mathrm{mg}, 0.001 \mathrm{mmol})$ and AgOTf $(0.6 \mathrm{mg}$, $0.001 \mathrm{mmol})$, were added aryl bromide $2(0.10 \mathrm{mmol})$ and toluene $(0.1 \mathrm{~mL})$. The resulting mixture was shaken by hand for $30 \mathrm{~s}$. Then, the solutions in these two vials above were combined. The vial was sealed with a PTFE-lined cap, removed from the dry box, and stirred at $50{ }^{\circ} \mathrm{C}$ for $12 \mathrm{~h}$. The reaction solution was condensed and purified by flash column chromatography to afford the pure product 6 .

General procedure for the $\alpha$-arylations of azetidine esters. In a dry and $\mathrm{N}_{2}$ filled glovebox, the small ring ester $7 \mathbf{d}(0.15 \mathrm{mmol})$ in toluene $(0.3 \mathrm{~mL})$ was added dropwise at room temperature to a $4 \mathrm{~mL}$ vial containing solid LiTMP $(23 \mathrm{mg}$, $0.16 \mathrm{mmol})$. The resulting mixture was allowed to stir for $15 \mathrm{~min}$ at RT. To a second vial containing $\mathrm{Pd}(\mathrm{dba})_{2}(2.9 \mathrm{mg}, 0.0050 \mathrm{mmol})$ and ${ }^{t} \mathrm{Bu}_{3} \mathrm{P}(1 \mathrm{M}$ in toluene, $5.0 \mu \mathrm{L}, 0.0050 \mathrm{mmol})$ were added aryl bromide $2(0.10 \mathrm{mmol})$ and toluene $(0.1 \mathrm{~mL})$. Then, the solutions in these two vials above were combined. The vial was sealed with a PTFE-lined cap, removed from the dry box, and stirred at $50^{\circ} \mathrm{C}$ for $12 \mathrm{~h}$. The reaction solution was condensed and purified by flash column chromatography to afford the pure product 8 .

\section{Data availability}

For experimental details and procedures, spectra for all unknown compounds, see supplementary files. The X-ray crystallographic data for $\mathbf{6 r}$ (CCDC 1823271), have been deposited at the Cambridge Crystallographic Data Center (www.ccdc.cam.ac.uk/ data_request/cif). All data underlying the findings of this study are available from the corresponding author upon reasonable request.

Received: 30 March 2019 Accepted: 14 August 2019

Published online: 09 September 2019

\section{References}

1. de Meijere, A., et al. Topics in Current Chemistry Vol. 207. p. 3 (SpringerVerlag, Berlin, 2010).

2. Talete, T. T. The "cyclopropyl fragment" is a versatile player that frequently appears in preclinical/clinical drug molecules. J. Med. Chem. 59, 8712-8756 (2016).

3. Seiser, T., Saget, T., Tran, D. N. \& Cramer, N. Cyclobutanes in catalysis. Angew. Chem. Int. Ed. 50, 7740-7752 (2010).

4. Antermite, D., Degennaro, L. \& Luisi, R. Recent advances in the chemistry of metallated azetidines. Org. Biomol. Chem. 15, 34 (2017).

5. Richard, D. T., MacCoss, M. \& Lawson, A. D. G. Rings in drugs. J. Med. Chem. 57, 5845-5859 (2014).

6. Gagnon, A., Duplessis, M. \& Fader, L. Arylcyclopropanes: properties, synthesis and use in medicinal chemistry. Org. Prep. Proced. Int. 42, 1-69 (2010).

7. Sabbatini, F. M. et al. Synthesis and pharmacological characterization of constrained analogues of vestipitant as in vitro potent and orally active NK1 receptor antagonists. Bioorg. Med. Chem. Lett. 20, 623-627 (2010).

8. Shuto, S., Ono, S., Imoto, H., Yoshii, K. \& Matsuda, A. Synthesis and biological activity of conformationally restricted analogues of milnacipran: $(1 S, 2 R)-1$ phenyl-2-[(R)-1-amino-2-propynyl]- $N, N$-diethylcyclopropanecarboxamide is a novel class of NMDA receptor channel blocker. J. Med. Chem. 41, 3507-3514 (1998).

9. Van Goor, F. et al. Correction of the F508del-CFTR protein processing defect in vitro by the investigational drug VX-809. Proc. Natl Acad. Sci. USA 108, 18843-18848 (2011).
10. Voight, E. A. et al. Stereoselective synthesis of a dipyridyl transient receptor potential vanilloid-3 (TRPV3) antagonist. J. Org. Chem. 81, 12060-12064 (2016).

11. Gundlah, C., Martin, K. F., Heal, D. J. \& Auerbach, S. B. In vivo criteria to differentiate monoamine reuptake inhibitors from releasing agents: sibutramine is a reuptake inhibitor. J. Pharmacol. Exp. Ther. 283, 581-591 (1997).

12. Zaghdane, H. et al. New indole amide derivatives as potent CRTH2 receptor antagonists. Bioorg. Med. Chem. Lett. 21, 3471-3474 (2011).

13. Billen, D., Greenwood, S. D. W., Stuk, T. L. Process for the preparation of chiral isoxazoline azetidine derivatives as antiparasitic agents. PCT Int. Appl. WO 2013116236, 2013.

14. Shi, W. et al. Discovery of 3,3'-spiro[azetidine]-2-oxo-indoline derivatives as fusion inhibitors for treatment of RSV infection. ACS Med. Chem. Lett. 9, 94-97 (2018).

15. Popovici-Muller, J., Saunders, J. O., Zahler, R., Cianchetta, G. Therapeutic compounds and compositions and their use as PKM2 modulators. PCT Int. Appl., WO 2014074848, 2014.

16. Palucki, M. \& Buchwald, S. L. Palladium-catalyzed $\alpha$-arylation of ketones. J. Am. Chem. Soc. 119, 11108-11109 (1997).

17. Hamann, B. C. \& Hartwig, J. F. Palladium-catalyzed direct $\alpha$-arylation of ketones. Rate acceleration by sterically hindered chelating ligands and reductive elimination from a transition metal enolate complex. J. Am. Chem. Soc. 119, 12382-12383 (1997)

18. Satoh, T., Kawamura, Y., Miura, M. \& Nomura, M. Palladium-catalyzed regioselective mono- and diarylation reactions of 2-phenylphenols and naphthols with aryl halides. Angew. Chem. Int. Ed. 36, 1740-1742 (1997)

19. Culkin, D. A. \& Hartwig, J. F. Palladium-catalyzed $\alpha$-arylation of carbonyl compounds and nitriles. Acc. Chem. Res. 36, 234-245 (2003).

20. Johansson, C. C. C. \& Colacot, T. J. Metal-catalyzed $\alpha$-arylation of carbonyl and related molecules: novel trends in $\mathrm{C}-\mathrm{C}$ bond formation by $\mathrm{C}-\mathrm{H}$ bond functionalization. Angew. Chem. Int. Ed. 49, 676-707 (2010).

21. Bellina, F. \& Rossi, R. Transition metal-catalyzed direct arylation of substrates with activated $\mathrm{sp}^{3}$-hybridized $\mathrm{C}-\mathrm{H}$ bonds and some of their synthetic equivalents with aryl halides and pseudohalides. Chem. Rev. 110, 1082-1146 (2010).

22. Moradi, W. A. \& Buchwald, S. L. palladium-catalyzed $\alpha$-arylation of esters. J. Am. Chem. Soc. 123, 7996-8002 (2001).

23. Lee, S., Beare, N. A. \& Hartwig, J. F. Palladium-catalyzed $\alpha$-arylation of esters and protected amino acids. J. Am. Chem. Soc. 123, 8410-8411 (2001).

24. Dunn, J. M. M., Kuethe, J. T., Orr, R. K., Tudge, M. \& Campeau, L.-C. Development of a palladium-catalyzed $\alpha$-arylation of cyclopropyl nitriles. Org. Lett. 16, 6314-6317 (2014).

25. Wright, B. A. \& Ardolino, M. J. Surprising reactivity in NiXantphos/ palladium-catalyzed $\alpha$-arylation of substituted cyclopropyl nitriles. J. Org. Chem. 84, 4670-4676 (2019).

26. Ruminski, P., Griggs, D. Preparation of $N$-glycyl-beta amino acid derivatives as integrin antagonists. PCT Int. Appl., WO 2014015054, 2014.

27. Carzaniga, L., et al. Preparation of quinolinone compounds having muscarinic receptor antagonist and $\beta 2$ adrenergic receptor agonist activity. U.S. Pat. Appl. Publ., 20160346271, 2016.

28. Naganawa, A., et al. Preparation of phenyl derivatives as S1P2 receptor antagonists. PCT Int. Appl., 2013047701, 2013.

29. Sakuma, D., Yamada, K., Sasazawa, K. \& Nishii, Y. Highly stereoselective carbon-carbon bond-forming reactions on cyclopropane rings using 1(methoxycarbonyl)cyclopropylzinc bromides. Chem. Lett. 44, 818-820 (2015).

30. Greszler, S. N., Halvorsen, G. T. \& Voight, E. A. Synthesis of substituted cyclopropanecarboxylates via room temperature palladium-catalyzed $\alpha$ arylation of reformatsky reagents. Org. Lett. 19, 2490-2493 (2017).

31. Dalziel, M. E., Chen, P., Carrera, D. E., Zhang, H. \& Gosselin, F. Highly diastereoselective $\alpha$-arylation of cyclic nitriles. Org. Lett. 19, 3446-3449 (2017).

32. Jørgensen, M., Liu, X., Wolkowski, J. P. \& Hartwig, J. F. Efficient synthesis of $a$-aryl esters by room-temperature palladium-catalyzed coupling of aryl halides with ester enolates. J. Am. Chem. Soc. 124, 12557-12565 (2002).

33. Hama, T. \& Hartwig, J. F. $\alpha$-arylation of esters catalyzed by the Pd(I) dimer $\left\{\left[\mathrm{P}(t-\mathrm{Bu})_{3}\right] \mathrm{PdBr}\right\}_{2}$. Org. Lett. 10, 1545-1548 (2008).

34. Gaertzen, O. \& Buchwald, S. L. Palladium-catalyzed intramolecular aarylation of $\alpha$-amino acid esters. J. Org. Chem. 67, 465-475 (2002).

35. Bercot, E. A. et al. Diastereoselective palladium-catalyzed $a$-arylation of 4substituted cyclohexyl esters. Org. Lett. 10, 5251-5254 (2008).

36. Larini, P. et al. On the mechanism of the palladium-catalyzed $\beta$-arylation of ester enolates. Chem. - Eur. J. 18, 1932-1944 (2012).

37. Melvin, P. R. et al. Design of a versatile and improved precatalyst scaffold for palladium-catalyzed cross-coupling: $\left(\eta^{3}-1-{ }^{t} \mathrm{Bu} \text {-indenyl }\right)_{2}(\mu-\mathrm{Cl})_{2} \mathrm{Pd}_{2}$. ACS Catal. 5, 3680-3688 (2015). 
38. Balcells, D. \& Nova, A. Designing Pd and Ni catalysts for cross-coupling reactions by minimizing off-cycle species. ACS Catal. 8, 3499-3515 (2018).

39. Chen, L., Sanchez, D. R., Zhang, B. \& Carrow, B. P. "Cationic" suzuki -miyaura coupling with acutely base-sensitive boronic acids. J. Am. Chem. Soc. 139, 12418-12421 (2017).

40. Martin, A., Vors, J.-P. \& Baudoin, O. Synthesis of conformationally constrained esters and amines by Pd-catalyzed $\alpha$-arylation of hindered substrates. ACS Catal. 6, 3941-3945 (2016).

41. D'hooge, M., Ha, H.-J. in Topics in heterocyclic chemistry (eds Maes, B. U. W., Cossy, J., Polanc, S.) Vol. 41 (Springer: New York, Vol. 41).

42. Wang, Z. et al. Catalytic enantioselective intermolecular desymmetrization of azetidines. J. Am. Chem. Soc. 137, 5895-5898 (2015).

43. Xu, C.-P., Xiao, Z.-H., Zhuo, B.-Q., Wang, Y.-H. \& Huang, P.-Q. Efficient and chemoselective alkylation of amines/amino acids using alcohols as alkylating reagents under mild conditions. Chem. Commun. 46, 7834-7836 (2010).

44. Verwijs, M. J., Karkare, R., Moore, M. D. Preparation of 3-(pyridin-2-yl) benzoic acid and 4-oxo-1H-quinoline-3-carboxamide derivative and pharmaceutical compositions for the treatment of CFTR mediated diseases. PCT Int. Appl., 2014071122, 2014.

45. Holan, G., Johnson, W. M. P., Jarvis, K. E., Virgona, C. T. \& Walser, R. A. Synthesis and insecticidal properties of ether analogues of DDT-pyrethroids. Pestic. Sci. 17, 715-723 (1986).

46. O’Hara, M., McGrath, P. J., D’Astous, J. \& Vair, C. A. Oral morphine versus injected meperidine (Demerol) for pain relief in children after orthopedic surgery. J. Pediatr. Orthop. 7, 78-82 (1987).

47. Culkin, D. A. \& Hartwig, J. F. C-C bond-forming reductive elimination of ketones, esters, and amides from isolated arylpalladium(II) enolates. J. Am. Chem. Soc. 123, 5816-5817 (2001).

48. Gorrichon, L., Maroni, P., Zedde, Ch \& Dobrev, A. Structure O-metallee de lithiocycloalcanecarboxylates de $t$-butyle. J. Organomet. Chem. 252, 267-274 (1983).

\section{Acknowledgements}

We thank Dow Chemicals for supporting this work.

\section{Author contributions}

Z.-T.H. conducted the experiments, collected, and analyzed the data. J.F.H. directed the project. Z.-T.H. and J.F.H. co-wrote the manuscript.

\section{Additional information}

Supplementary Information accompanies this paper at https://doi.org/10.1038/s41467 019-12090-z.

Competing interests: The authors declare no competing interests.

Reprints and permission information is available online at http://npg.nature.com/ reprintsandpermissions/

Peer review information: Nature Communications thanks Valentin Hornillos and other anonymous reviewer(s) for their contribution to the peer review of this work.

Publisher's note: Springer Nature remains neutral with regard to jurisdictional claims in published maps and institutional affiliations.

(c) Open Access This article is licensed under a Creative Commons Attribution 4.0 International License, which permits use, sharing, adaptation, distribution and reproduction in any medium or format, as long as you give appropriate credit to the original author(s) and the source, provide a link to the Creative Commons license, and indicate if changes were made. The images or other third party material in this article are included in the article's Creative Commons license, unless indicated otherwise in a credit line to the material. If material is not included in the article's Creative Commons license and your intended use is not permitted by statutory regulation or exceeds the permitted use, you will need to obtain permission directly from the copyright holder. To view a copy of this license, visit http://creativecommons.org/ licenses/by/4.0/.

(C) The Author(s) 2019 